\title{
Complete genome sequence of Pseudomonas brassicacearum strain L13-6-12, a biological control agent from the rhizosphere of potato
}

\author{
Christin Zachow ${ }^{1,2^{*}}$ D, Henry Müller ${ }^{2}$, Jana Monk ${ }^{3}$ and Gabriele Berg ${ }^{2}$
}

\begin{abstract}
Pseudomonas brassicacearum strain L13-6-12 is a rhizosphere colonizer of potato, lettuce and sugar beet. Previous studies have shown that this motile, Gram-negative, non-sporulating bacterium is an effective biocontrol agent against different phytopathogens. Here, we announce and describe the complete genome sequence of $P$. brassicacearum L13-6-12 consisting of a single $6.7 \mathrm{Mb}$ circular chromosome that consists of 5773 protein coding genes and 85 RNA-only encoding genes. Genome analysis revealed genes encoding specialized functions for pathogen suppression, thriving in the rhizosphere and interacting with eukaryotic organisms.
\end{abstract}

Keywords: Short genome report, Pseudomonadaceae, Pseudomonas brassicacearum L13-6-12, Potato rhizosphere, Volatile organic compounds, Biocontrol, Plant growth promotion, Secretion systems

\section{Introduction}

Pseudomonas brassicacearum strain L13-6-12 was isolated from the rhizosphere of a field grown potato plant [1]. L13-6-12 was selected as effective biological control agent with disease-suppressing effects against Rhizoctonia solani Kühn in treated lettuce and potato plants in greenhouse and field trials [2]. It has additional antifungal activity against the phytopathogenic fungi Alternaria alternata, Botrytis cinerea Pers. DSM5145, Penicillium italicum, Phoma betae, Sclerotinia sclerotiorum, Verticillium dahliae Kleb. V25 (all Ascomycota) and Rhizoctonia solani AG22IIIB and AG4 and Sclerotium rolfsii (Basidiomycota). This biocontrol activity is linked to the production of secondary metabolites, including 2,4-diacetylphloroglucinol and hydrogen cyanide. For various strains of plantassociated pseudomonads the production of antifungal metabolites like DAPG and recombinase genes were identified as the major trait for biological control of

\footnotetext{
* Correspondence: christin.zachow@acib.at

${ }^{1}$ Austrian Centre of Industrial Biotechnology (ACIB GmbH), Petersgasse 14, 8010 Graz, Austria

${ }^{2}$ Institute of Environmental Biotechnology, Graz University of Technology,

Petersgasse 12, 8010 Graz, Austria

Full list of author information is available at the end of the article
}

soilborne pathogens and plant root colonization [3]. Genes in L13-6-12 predicting functions for biocontrol include factors such as secreted proteases and comprehensive secretion systems. It also supports plant growth by nutrient delivery by phosphate solubilization, production of indole-3-acetic acid as well as by aminocyclopropane-1carboxylate deaminase activity. Additionally, L13-6-12 copes with abiotic stresses such as desiccation and high salt concentrations. To gain insight into ecological relevant traits and to improve its biotechnological applications we sequenced the complete genome of this bacterium.

\section{Organism information Classification and features}

P. brassicacearum L13-6-12 is a motile, Gram-negative, non-sporulating rod in the order Pseudomonadales of the class Gammaproteobacteria. The rod-shaped cells are approximately $0.4 \mu \mathrm{m}$ in width and $0.8-1.5 \mu \mathrm{m}$ in length (Fig. 1 left). The strain is moderately fast-growing, forming $1 \mathrm{~mm}$ colonies within $1-2$ days at $25^{\circ} \mathrm{C}$. Colonies formed on NBII agar plates are yellow shining, domed and moderately mucoid with smooth margins (Fig. 1 right). Cultivation for more than two weeks on NA result in a color change of the medium to dark brown. L13-6-12 

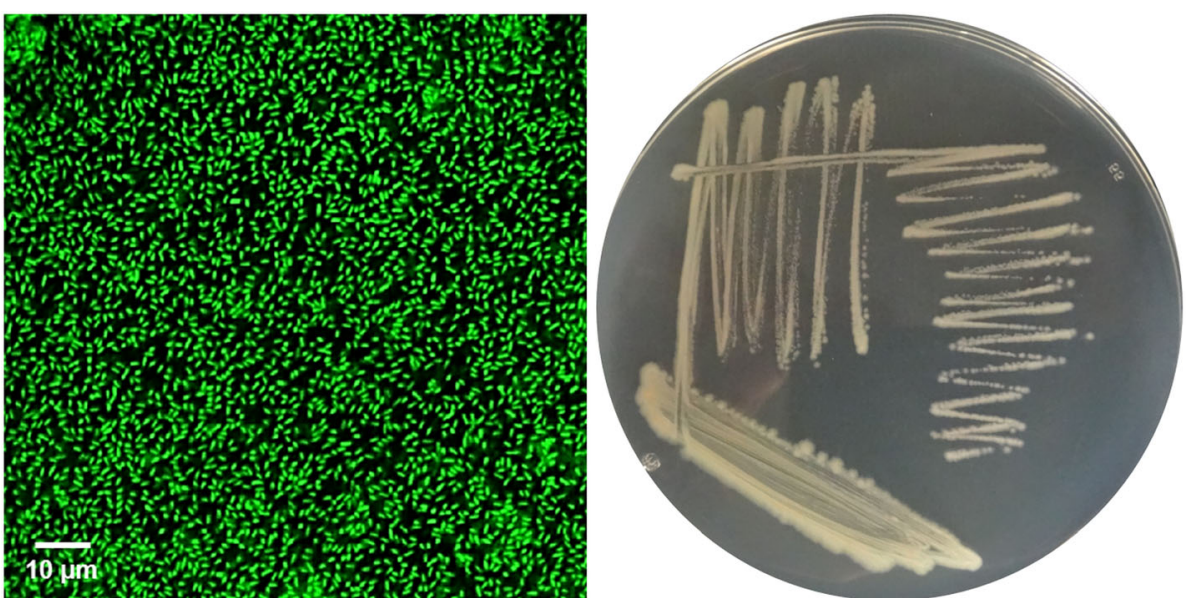

Fig. 1 Photomicrographs of source organism. Images of P. brassicacearum L13-6-12 cells using confocal laser scanning microscopy (CLSM, left) and the appearance of colony morphology after $48 \mathrm{~h}$ growing on NB agar at $25^{\circ} \mathrm{C}$ (right). Image was obtained using acridin orange $\left(0.4 \mathrm{mg} \mathrm{ml}{ }^{-1}\right.$ water) stained L13-6-12 cells with 40x magnification. Cells were visualized with Leica TCS SP CLSM (Leica Microsystems, Wetzlar, Germany) and analysed using Leica Application Suite Advanced Fluorescence (LAS AF) software Version 3.5

was isolated from a potato rhizosphere from plants grown in a field trial in Groß Lüsewitz, Germany, in 1997 [1].

Even though the optimal growth temperature is $30{ }^{\circ} \mathrm{C}$, L13-6-12 can also slowly replicate at $5{ }^{\circ} \mathrm{C}$ in liquid Luria Bertani medium. Growth was observed at $37{ }^{\circ} \mathrm{C}$ and slightly at $40{ }^{\circ} \mathrm{C}$ in this culturing medium as well as on solidified medium after $24 \mathrm{~h}$. The strain grows in complex media, but not in Standard Succinate Medium (pH 7.0). Optimum pH for growth in LB is $\mathrm{pH}$ 7.0. The bacterium is an efficient colonizer of lettuce, potato [2, $3]$ and sugar beet plants, where microcolonies consisted of tens to hundreds of bacterial cells, forming an interconnected network between epidermal cells in the rhizoplane [3]. It does not cause any deleterious effect on its original host plant potato or lettuce $[1,2]$ and sugar beet [4] or on the nematode Caenorhabditis elegans [5]. Strain L13-6-12 has natural resistance to gentamycin $(10 \mu \mathrm{g} \mathrm{mL}$ $\left.{ }^{-1}\right)$, trimethoprim $\left(50 \mu \mathrm{g} \mathrm{mL} L^{-1}\right)$ and is able to develop spontaneous rifampicin-resistance.

Minimum Information about the Genome Sequence of P. brassicacearum L13-6-12 is summarized in Table 1. The phylogenetic relationship of $P$. brassicacearum L136-12 to other species within the genus Pseudomonas is visualized in a 16S rRNA based tree (Fig. 2) [6].

\section{Genome sequencing information \\ Genome project history}

Strain L13-6-12 was originally assigned to P. fluorescens based on 16S rRNA gene sequencing and alignments with NCBI database [1, 2, 4, 5]. After average nucleotide identity [7] comparison of the genome sequence against the genomes of the type strains and proxytype strains that are already in GenBank, L13-6-12 showed 99.604\% identity to the type genome of $P$. brassicacearum with
95.5\% coverage of the genome. The genome of P. brassicacearum strain L13-6-12 was selected for sequencing based on its ability to exert biocontrol abilities against fungal pathogens and to promote plant growth $[1,3]$. This whole-genome shotgun project has been deposited in the NCBI database under the accession no. CP014693. The version described in this paper is the first version (Table 2).

\section{Growth conditions and genomic DNA preparation}

$P$. brassicacearum strain L13-6-12 was grown in $50 \mathrm{~mL}$ of NBII (Sifin, Berlin, Germany) medium and incubated for $20 \mathrm{~h}$ at $30{ }^{\circ} \mathrm{C} .1 .0 \mathrm{~mL}$ was centrifuged at $2500 \times \mathrm{g}$ for 5 min at $4{ }^{\circ} \mathrm{C}$ and genomic DNA was extracted using the MasterPure DNA purification kit (Epicentre, Madison, WI, USA). DNA quality and quantity were validated by agarose gel electrophoresis and spectrophotometry using a UV-Vis spectrophotometer (NanoDrop 2000c, Thermo Fisher Scientific, Waltham, MA USA). In total, $54 \mu \mathrm{g}$ genomic DNA (1.8 $\left.\mu \mathrm{g} \mu \mathrm{L}^{-1}\right)$ was sent on dry ice to the sequencing service. PacBio RS libraries with inserts of 8 to $20 \mathrm{~kb}$ were constructed and sequenced at GATC Biotech (Konstanz, Germany).

\section{Genome sequencing and assembly}

PacBio RS libraries with inserts of 8 to $20 \mathrm{~kb}$ were constructed and sequenced at GATC Biotech (Konstanz, Germany) using single molecule, real-time sequencing. Assembly was completed with the Hierarchical Genome Assembly Process algorithm implemented in the PacBio SMRT Analysis software (Pacific Biosciences, Menlo Park, CA, USA). The assembly of L13-6-12 genome based on 130,283 quality reads with a mean length of 4995 bp resulting in a single circular chromosome consisting of 
Table 1 Classification and general features of P. brassicacearum strain L13-6-12 according to the MIGS recommendation [29]

\begin{tabular}{|c|c|c|c|}
\hline MIGS ID & Property & Term & Evidence code \\
\hline & Classification & Domain Bacteria & TAS [30] \\
\hline & & Phylum Proteobacteria & TAS [31] \\
\hline & & Class Gammaproteobacteria & TAS [32] \\
\hline & & Order Pseudomonadales & $\operatorname{TAS}[33,34]$ \\
\hline & & Family Pseudomonadaceae & $\operatorname{TAS}[31,35]$ \\
\hline & & Genus Pseudomonas & TAS [36-39] \\
\hline & & Species Pseudomonas brassicacearum & TAS [39] \\
\hline & & Strain: L13-6-12 & TAS [1] \\
\hline & Gram stain & Negative & IDA, TAS [39] \\
\hline & Cell shape & Rod & IDA, TAS [39] \\
\hline & Motility & Motile & TAS [39] \\
\hline & Sporulation & Not reported & NAS \\
\hline & Temperature range & $5^{\circ} \mathrm{C}-40^{\circ} \mathrm{C}$ & IDA \\
\hline & Optimum temperature & $30^{\circ} \mathrm{C}$ & IDA \\
\hline & pH range; Optimum & $5.0-9.0 ; 7$ & IDA \\
\hline & Carbon source & Heterotrophic & TAS [39] \\
\hline MIGS-6 & Habitat & Potato, Rhizosphere & TAS [1] \\
\hline MIGS-6.3 & Salinity & $1.0-9.0 \% \mathrm{NaCl}(\mathrm{w} / \mathrm{v})$ & IDA, TAS [1] \\
\hline MIGS-22 & Oxygen requirement & Aerobic & TAS [39] \\
\hline MIGS-15 & Biotic relationship & Rhizospheric & $\operatorname{TAS}[1,2,4]$ \\
\hline MIGS-14 & Pathogenicity & Non-pathogen & $\operatorname{TAS}[1,5]$ \\
\hline MIGS-4 & Geographic location & Gross Luesewitz, Germany & TAS [1] \\
\hline MIGS-5 & Sample collection & 2001 & TAS [1] \\
\hline MIGS-4.1 & Latitude & $54^{\circ} 4^{\prime} 15.4704^{\prime \prime} N$ & NAS \\
\hline MIGS-4.2 & Longitude & $12^{\circ} 20^{\prime} 19.9248^{\prime \prime} \mathrm{E}$ & NAS \\
\hline MIGS-4.4 & Altitude & $37 \mathrm{~m}$ & NAS \\
\hline
\end{tabular}

${ }^{a}$ Evidence codes - IDA: Inferred from Direct Assay; TAS: Traceable Author Statement (i.e., a direct report exists in the literature); NAS: Non-traceable Author Statement (i.e., not directly observed for the living, isolated sample, but based on a generally accepted property for the species, or anecdotal evidence). These evidence codes are from the Gene Ontology project [40]

6,715,909 bp, with 84.9-fold overall coverage and a GC content of $60.7 \%$.

\section{Genome annotation}

Automatic annotation was conducted on the RAST Web server (version 36) using RAST gene calling based on FIGfam version Release70 [8, 9], and additional annotation for using the automated assignment of COGfunctions to protein-coding genes was completed on the BASys web server using Glimmer gene prediction $[10,11]$. Pseudogenes were predicted using the NCBI Prokaryotic Genome Annotation Pipeline. Signal peptides and transmembrane helices were predicted using SignalP $[12,13]$ and TMHMM $[14,15]$.

\section{Genome properties}

The genome of L13-6-12 is composed of one circular chromosome consisting of $6,715,909$ bp with an average
GC content of $60.7 \%$ (Table 3 and Fig. 3), which is similar to that of other P. brassicacearum strains. Among the 5887 predicted genes, 5773 were identified as protein coding genes. Of the last, $4801(83.2 \%)$ were assigned a putative function, while the other 972 (16.8\%) were designated as hypothetical proteins. The classification of CDSs into functional categories according to the COG $[16,17]$ database is summarized in Table 4 based on BASys gene prediction. Beside the predicted genes, the genome annotation contained 65 tRNA, five rRNA loci (5S, 16S, 23S) with one additional 5S rRNA, four ncRNAs and 284 predicted SEED subsystem features.

\section{Insights from the genome sequence}

The genome-wide phylogenetic analysis on different Pseudomonas species with the L13-6-12 genome showed that strain L13-6-12 clusters closely to P. fluorescens Q8r1-96 (NCBI Accession no. PRJNA67537) (Fig. 2). 


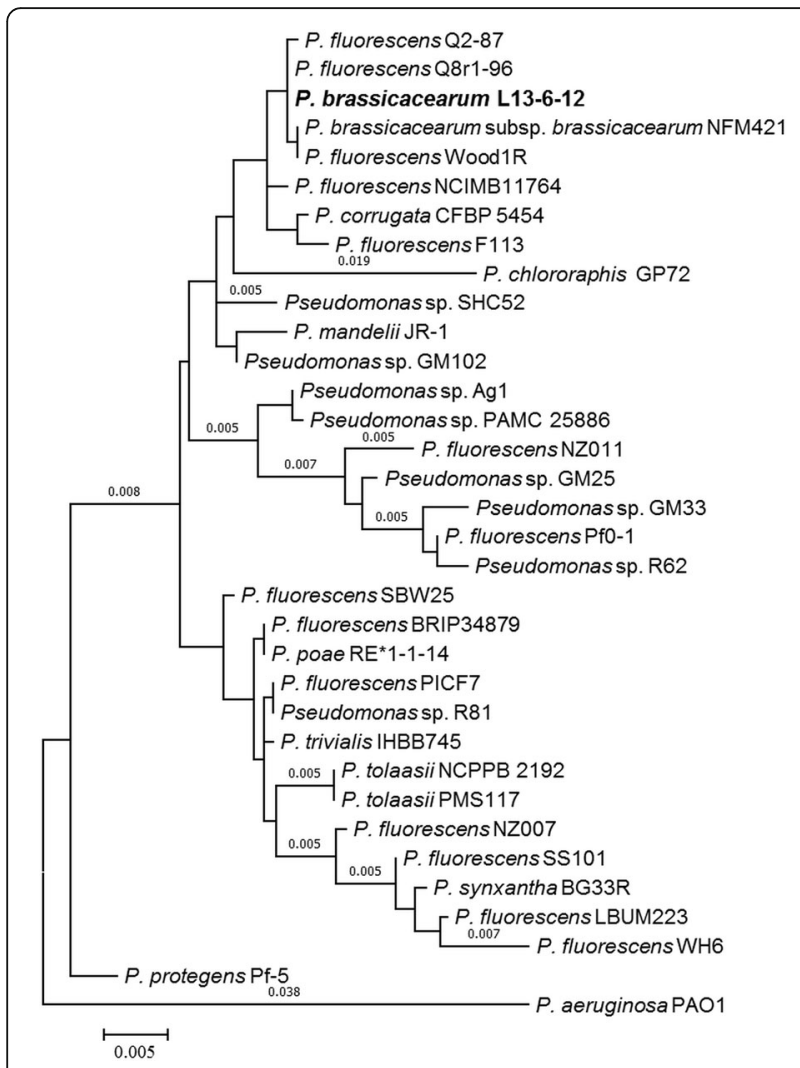

Fig. 2 Phylogenetic tree showing the position of $P$. brassicacearum L13-6-12 in relationships among other strains of Pseudomonas spp. including $P$. aeruginosa PAO1 as outgroup. The tree is based on 165 rRNA gene alignments and was conducted in MEGA6 [41]. Initial tree for the heuristic search were obtained automatically by applying Neighbor-Join and BioNJ algorithms to a matrix of pairwise distances estimated using the Maximum Composite Likelihood approach, and then selecting the topology with superior log likelihood value
Recently, Q8r1-96 was described as a biological control strain that produces the antibiotic DAPG and that exceptionally colonizes the roots of wheat and pea $[18,19]$. The genome of L13-6-12 contains several genes, which are important contributors to biological control. They are related to the biosynthesis of secondary metabolites or antimicrobial products that are similar to those found in the genomes of other Pseudomonads [20]. We detected genes for the biosynthesis of DAPG (Locus tags: A0U95_04640, A0U95_04655, A0U95_04660, A0U95_04665) and productions of exoproteases (A0U95_00125, A0U95_02755). The suppression of hyphal growth of $S$. rolfsii by volatile organic compounds produced by L13-6-12 was observed in a test system developed by Cernava et al. [21]. Volatile components have been shown to act as antibiotics and to induce plant growth [22, 23]. Hydrogen cyanide $(\mathrm{HCN})$ is an inorganic volatile compound with antagonistic effects against soil microbes [24]. The production of $\mathrm{HCN}$ was observed in L13-6-12 (A0U95_28525) by applying an assay according
Table 2 Project information

\begin{tabular}{|c|c|c|}
\hline MIGS ID & Property & Term \\
\hline MIGS 31 & Finishing quality & Finished \\
\hline MIGS-28 & Libraries used & PacBio RS libraries with inserts of 8 to $20 \mathrm{~kb}$ \\
\hline MIGS 29 & $\begin{array}{l}\text { Sequencing } \\
\text { platforms }\end{array}$ & PacBio RS II sequencer \\
\hline MIGS 31.2 & Fold coverage & 84.9 \\
\hline MIGS 30 & Assemblers & $\begin{array}{l}\text { Hierarchical Genome Assembly Process } \\
\text { algorithm implemented in the PacBio } \\
\text { SMRT Analysis software }\end{array}$ \\
\hline \multirow[t]{6}{*}{ MIGS 32} & $\begin{array}{l}\text { Gene calling } \\
\text { method }\end{array}$ & $\begin{array}{l}\text { Glimmer gene prediction, NCBI Prokaryotic } \\
\text { Genome Annotation Pipeline }\end{array}$ \\
\hline & Locus Tag & A0U95 \\
\hline & Genbank ID & СР014693 \\
\hline & $\begin{array}{l}\text { GenBank Date } \\
\text { of Release }\end{array}$ & September 20, 2016 \\
\hline & GOLD ID & Gs0118536, Gp0137088 \\
\hline & BIOPROJECT & PRJNA311625 \\
\hline \multirow[t]{2}{*}{ MIGS 13} & $\begin{array}{l}\text { Source Material } \\
\text { Identifier }\end{array}$ & L13-6-12 \\
\hline & Project relevance & $\begin{array}{l}\text { Plant-bacteria interaction, agricultural, } \\
\text { environmental }\end{array}$ \\
\hline
\end{tabular}

to Blom et al. [25]. Genes predicting biosynthesis of other volatile components such as 2,3-butanediol (A0U95_29290) and acetoin (A0U95_29285) were found as well.

We further identified genes most probably involved in the direct promotion of plant growth, such as biosynthesis or carrier gene clusters for spermidine (A0U95_07830), pyoverdine (e.g. A0U95_07605, A0U95_25745, A0U95_25750) and aminocyclopropane-1-carboxylate (ACC) deaminase

Table 3 Genome statistics

\begin{tabular}{lrc}
\hline Attribute & \multicolumn{1}{c}{ Value } & \% of Total \\
\hline Genome size (bp) & $6,715,909$ & 100 \\
DNA coding (bp) & $6,050,433$ & 90.1 \\
DNA G + C (bp) & $4,091,158$ & 60.7 \\
DNA scaffolds & 1 & - \\
Total genes & 5887 & 100 \\
Protein coding genes & 5773 & 98.1 \\
RNA genes & 85 & 1.4 \\
Pseudo genes & 29 & 0.5 \\
Genes in internal clusters & NA & - \\
Genes with function prediction & 4801 & 83.2 \\
Genes assigned to COGs & 4481 & 77.6 \\
Genes with Pfam domains & 3770 & 65.3 \\
Genes with signal peptides & 390 & 6.8 \\
Genes with transmembrane helices & 1389 & 24.1 \\
CRISPR repeats & NA & - \\
\hline
\end{tabular}




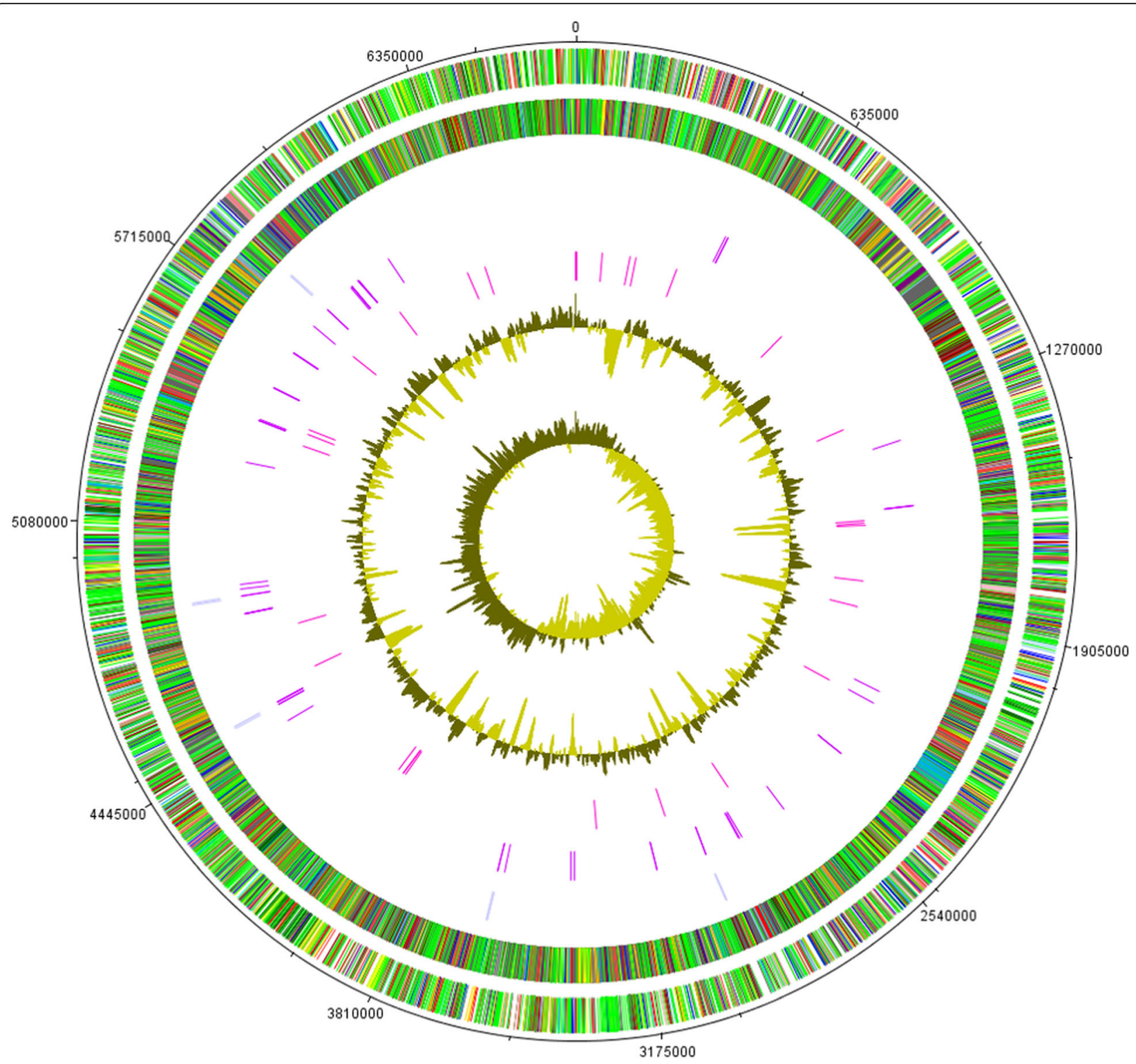

Fig. 3 Graphical map of the chromosome. The outer scale is marked every $50 \mathrm{~kb}$. Circles range from 1 (outer circle) to 7 (inner circle). Circle 1 and 2, ORFs encoded by leading and lagging strand respectively, with color code for functions: salmon, translation, ribosomal structure and biogenesis; aquamarine, RNA processing and modification; light blue, transcription; cyan, DNA replication, recombination and repair; tan, chromatin structure and dynamics; turquoise, cell division; dark orange, defense mechanisms; deep pink, post-translational modification, protein turnover and chaperones; dark olive green, cell envelope biogenesis; purple, cell motility and secretion; lavender, intracellular trafficking, secretion, and vesicular transport; forest green, inorganic ion transport and metabolism; pink, signal transduction; red, energy production; sienna, carbohydrate transport and metabolism; yellow, amino acid transport; orange, nucleotide transport and metabolism; gold, co-enzyme transport and metabolism; cornflower blue, lipid metabolism; blue, secondary metabolites, transport and catabolism; gray, general function prediction only; yellow green, unknown function; black, function unclassified or unknown. Circle 3 and 4, distributions of tRNA genes and rrn operons respectively. Circle 5, distribution of pseudogenes. Circle 6 and 7, G+C content and GC skew (G-C/G +C) respectively

(A0U95_06530). ACC deaminase is suggested to be a key in the modulation of ethylene levels in plants by bacteria [26].

For secretion of extracellular proteins in the surrounding environment genes putatively encoding general secretory pathway proteins (Gsp) belonging to the type two secretion systems were found in L13-6-12 (e.g. A0U95_29195, A0U95_29200, A0U95_29205). Type six secretion systems have evolved in Gram-negative bacteria enabling them to interact with their host and to adapt to various microenvironments and specialized functions [27, 28]. Genes encoding components of the type six secretion system were found in L13-6-12 (e.g. A0U95_16935, A0U95_28720, A0U95_28755) putatively for interaction with eukaryotic organisms. 
Table 4 Number of genes associated with general COG functional categories

\begin{tabular}{|c|c|c|c|}
\hline Code & Value & \%age & Description \\
\hline J & 2 & 0.03 & Translation, ribosomal structure and biogenesis \\
\hline A & 3 & 0.04 & RNA processing and modification \\
\hline K & 281 & 4.21 & Transcription \\
\hline $\mathrm{L}$ & 32 & 0.48 & Replication, recombination and repair \\
\hline B & 545 & 8.16 & Chromatin structure and dynamics \\
\hline D & 81 & 1.21 & Cell cycle control, Cell division, chromosome partitioning \\
\hline V & 284 & 4.25 & Defense mechanisms \\
\hline $\mathrm{T}$ & 162 & 2.43 & Signal transduction mechanisms \\
\hline M & 211 & 3.16 & Cell wall/membrane biogenesis \\
\hline N & 165 & 2.47 & Cell motility \\
\hline U & 442 & 6.62 & Intracellular trafficking and secretion \\
\hline O & 153 & 2.29 & Posttranslational modification, protein turnover, chaperones \\
\hline C & 256 & 3.83 & Energy production and conversion \\
\hline G & 158 & 2.37 & Carbohydrate transport and metabolism \\
\hline$E$ & 174 & 2.61 & Amino acid transport and metabolism \\
\hline $\mathrm{F}$ & 239 & 3.58 & Nucleotide transport and metabolism \\
\hline H & 112 & 1.68 & Coenzyme transport and metabolism \\
\hline । & 468 & 7.01 & Lipid transport and metabolism \\
\hline$P$ & 344 & 5.15 & Inorganic ion transport and metabolism \\
\hline Q & 263 & 3.94 & Secondary metabolites biosynthesis, transport and catabolism \\
\hline R & 50 & 0.75 & General function prediction only \\
\hline S & 56 & 0.84 & Function unknown \\
\hline- & 3201 & 47.93 & Not in COGs \\
\hline
\end{tabular}

The total is based on the total number of protein coding genes in the genome based on BASys gene prediction

\section{Conclusions}

In this report, we describe the complete genome sequence of Pseudomonas brassicacearum strain L13-6-12, a strain that was originally isolated from the rhizosphere of potato grown in Groß Lüsewitz, Germany and which was originally assigned as P. fluorescens. This strain was selected for sequencing based on its ability to protect plants from biotic stresses and to promote plant growth. It also has a collection of genes predicting volatile components and enzymes such as a protease, ACC deaminase and spermidine enabling L13-6-12 to protect and promote its host plant. Genes, encoding putative T2SS, T4SS and T6SS, allowing interactions with the host and the environment were detected, too. Further functional studies and comparative genomics with related isolates will provide insights into mechanisms useful for novel biotechnological processes for seed and root applications since the strain represent a promising candidate for improving of plant performance.

\section{Abbreviations}

CDS: Coding DNA sequence; CLSM: Confocal laser scanning microscopy; COG: Clusters of Orthologous Groups; DAPG: 2,4-diacetylphloroglucinol; HCN: Hydrogen cyanide; HGAP: Hierarchical Genome Assembly Process;
LB: Luria Bertani; NAll: Nutrient Broth II agar; NBII: Nutrient Broth Il; RAST: Rapid annotations using subsystems technology; SMRT: Single molecule, real-time; SSM: Standard Succinate Medium; T2SS: Type 2 secretion system

\section{Acknowledgements}

The Authors thank Barbara Fetz for valuable assistance in DNA preparation. We are thankful to Eveline Adam and John H. Allan for performing growth experiments at different temperatures and $\mathrm{pH}$ values.

\section{Funding}

This work has been supported by the Federal Ministry of Science, Research and Economy (BMWFW), the Federal Ministry of Traffic, Innovation and Technology, the Styrian Business Promotion Agency SFG, the Standortagentur Tirol, the Government of Lower Austria and ZIT - Technology Agency of the City of Vienna through the COMET-Funding Program managed by the Austrian Research Promotion Agency FFG.

\section{Authors' contributions}

$\mathrm{CZ}, \mathrm{HM}$ and $\mathrm{GB}$ conceived and designed the experiments. CZ and JM performed the phenotypic characterization. HM and CZ performed the annotation and sequence homology searches. CZ wrote the manuscript. All authors commented on the manuscript before submission. All authors read and approved the final manuscript.

\section{Competing interests}

The authors declare that they have no competing interests.

\section{Author details}

${ }^{1}$ Austrian Centre of Industrial Biotechnology (ACIB GmbH), Petersgasse 14, $8010 \mathrm{Graz}$, Austria. Institute of Environmental Biotechnology, Graz University 
of Technology, Petersgasse $12,8010 \mathrm{Graz}$, Austria. ${ }^{3}$ Faculty of Agriculture and Life Sciences, Department of Ecology, Lincoln University, Ellesmere Junction Road, Lincoln 7647, New Zealand.

Received: 24 May 2016 Accepted: 5 December 2016

Published online: 09 January 2017

\section{References}

1. Lottmann J, Heuer H, Smalla K, Berg G. Influence of transgenic T4-lysozymeproducing plants on beneficial plant-associated bacteria. FEMS Microbiol Ecol. 1999:29:365-77.

2. Grosch R, Faltin F, Lottmann J, Kofoet A, Berg G. Effectiveness of 3 antagonistic bacterial isolates to control Rhizoctonia solani Kühn on lettuce and potato. Can J Microbiol. 2005;51(4):345-53.

3. Raaijmakers JM, Weller DM. Exploiting Genotypic Diversity of 2,4diacetylphloroglucinol-producing Pseudomonas spp.: Characterization of superior root-colonizing P. fluorescens strain Q8r1-96. Appl Environ Microb. 2001;67(6):2545-54.

4. Zachow C, Fatehi J, Cardinale M, Tilcher R, Berg G. Strain-specific colonization pattern of Rhizoctonia antagonists in the root system of sugar beet. FEMS Microbiol Ecol. 2010;74(1):124-35.

5. Zachow C, Pirker H, Westendorf C, Tilcher R, Berg G. The Caenorhabditis elegans assay: a tool to evaluate the pathogenic potential of bacterial biocontrol agents. Europ Plant Pathol. 2009:125(3):367-76.

6. Loper JE, Hassan KA, Mavrodi DV, Davis II EW, Lim CK, Shaffer BT, et al. Comparative genomics of plant-associated Pseudomonas spp.: insights into diversity and inheritance of traits involved in multitrophic interactions. PLoS Genet. 2012;8(7):e1002784.

7. Federhen S, Rossello-Mora R, Klenk HP, Tindall BJ, Konstantinidis KT, Whitman WB, et al. Meeting report: GenBank microbial genomic taxonomy workshop (12-13 May, 2015). Standards Genomic Sci. 2016;11(1):1.

8. Aziz RK, Bartels D, Best AA, DeJongh M, Disz T, Edwards RA, et al. The RAST server: rapid annotations using subsystems technology. BMC Genomics. 2008;9:75.

9. Overbeek R, Olson R, Pusch GD, Olsen GJ, Davis JJ, Disz T, et al. The SEED and the rapid annotation of microbial genomes using subsystems technology (RAST). Nucleic Acids Res. 2014;42:D206-14

10. Van Domselaar GH, Stothard P, Shrivastava S, Cruz JA, Guo A, Dong X, Lu P, Szafron D, Greiner R, Wishart DS. BASys: a web server for automated bacterial genome annotation. Nucleic Acids Res. 2005:33:W455-59.

11. Delcher AL, Harmon D, Kasif S, White O, Salzberg SL. Improved microbial gene identification with Glimmer. Nucleic Acids Res. 1999;27:4636-41.

12. Petersen TN, Brunak S, von Heijne G, Nielsen H. SignalP 4.0: discriminating signal peptides from transmembrane regions. Nat Methods. 2011;8:785-6.

13. Emanuelsson $\mathrm{O}$, Brunak $\mathrm{S}$, von Heijne $\mathrm{G}$, Nielsen $\mathrm{H}$. Locating proteins in the cell using TargetP, SignalP and related tools. Nat Protoc. 2007;2:953-71.

14. Krogh A, Larsson B, von Heijne G, Sonnhammer EL. Predicting transmembrane protein topology with a hidden Markov model: application to complete genomes. J Mol Biol. 2001;305:567-80.

15. TMHMM Server v. 2.0. Prediction of transmembrane helices in proteins. Center for Biological Sequence Analysis. Technical University of Denmark DTU, Lyngby. 2015. www.cbs.dtu.dk/services/TMHMM/. Accessed Feb 2016.

16. Tatusov RL, Koonin EV, Lipman DJ. A genomic perspective on protein families. Science. 1997;278:631-7.

17. Galperin MY, Makarova KS, Wolf YI, Koonin EV. Expanded microbial genome coverage and improved protein family annotation in the COG database. Nucleic Acids Res. 2014. doi:10.1093/nar/gku1223.

18. Mavrodi OV, Mavrodi DV, Park AA, Weller DM, Thomashow LS. The role of $d s b A$ in colonization of the wheat rhizosphere by Pseudomonas fluorescens Q8r1-96. Microbiol. 2006;152(3):863-72.

19. Mavrodi DV, Joe A, Mavrodi OV, Hassan KA, Weller DM, Paulsen IT, Loper JE, Alfano JR, Thomashow LS. Structural and functional analysis of the type III secretion system from Pseudomonas fluorescens Q8r1-96. J Bacteriol. 2011; 193(1):177-89.

20. Van Der Voort M, Meijer HJ, Schmidt Y, Watrous J, Dekkers E, Mendes R, Dorestein PC, Gross H, Raaijmakers JM. Genome mining and metabolic profiling of the rhizosphere bacterium Pseudomonas sp. SH-C52 for antimicrobial compounds. Front Microbiol. 2015;6.

21. Cernava T, Aschenbrenner IA, Grube M, Liebminger S, Berg G. A novel assay for the detection of bioactive volatiles evaluated by screening of lichenassociated bacteria. Front Microbiol. 2015;6. doi:10.3389/fmicb.2015.00398.
22. Ren Y, Strobel G, Sears J, Park M. Geobacillus sp., a thermophilic soil bacterium producing volatile antibiotics. Microb Ecol. 2010;60:130-6.

23. Ryu CM, Farag MA, Hu CH, Reddy MS, Wei HX, Paré PW, et al. Bacterial volatiles promote growth in Arabidopsis. Proc Natl Acad Sci U S A. 2003; 100:4927-32.

24. Ahmad F, Ahmad I, Khan MS. Screening of free-living rhizospheric bacteria for their multiple plant growth promoting activities. Microbiol Res. 2008;163:173-81.

25. Blom D, Fabbri C, Eberl L, Weisskopf L. Volatile-mediated killing of Arabidopsis thaliana by bacteria is mainly due to hydrogen cyanide. Appl Environ Microbiol. 2011:77(3):1000-8.

26. Hardoim PR, van Overbeek LS, van Elsas JD. Properties of bacterial endophytes and their proposed role in plant growth. Trends Microbiol. 2008;16:463-71.

27. Bleves S, Viarre V, Salacha R, Michel GP, Filloux A, Voulhoux R. Protein secretion systems in Pseudomonas aeruginosa: a wealth of pathogenic weapons. Int J Med Microbiol. 2010;300(8):534-43.

28. Boyer F, Fichant G, Berthod J, Vandenbrouck Y, Attree I. Dissecting the bacterial type VI secretion system by a genome wide in silico analysis: what can be learned from available microbial genomic resources? BMC Gen. 2009;10(1):1.

29. Field D, Garrity G, Gray T, Morrison N, Selengut J, Sterk P, et al. The minimum information about a genome sequence (MIGS) specification. Nat Biotechnol. 2008;26:541-7.

30. Woese CR. Towards a natural system of organisms: proposal for the domains archaea, bacteria and eucarya. Proc Natl Acad Sci U S A. 1990:87:4576-9.

31. Garrity GM, Bell JA, Lilburn T: Phylum XIV. Proteobacteria phyl. nov. In: Garrity GM, Brenner D, Krieg N, Staley J, editors. Bergey's Manual of Systematic Bacteriology, Volume 2, Part B. 2nd ed. New York: Springer; 2005: p. 323

32. Garrity GM, Bell JA, Class LT. III. Gammaproteobacteria class. nov. In: Bergey's Manual of Systematics of Archaea and Bacteria, John Wiley \& Sons, Inc. New York: Part B; 2015: p. 1. doi: 10.1002/9781118960608.cbm00045

33. Skerman VBD, McGowan V. Sneath PHA. Approved lists of bacterial names. Int J Syst Bacteriol. 1980;30:225-420.

34. Orla-Jensen S. The main lines of the natural bacterial system. J Bacteriol. $1921 ; 6: 263-73$

35. Winslow CEA, Broadhurst J, Buchanan RE, Krumwiede C, Rogers LA, Smith $\mathrm{GH}$. The families and genera of the bacteria. Preliminary report of the committee of the society of American Bacteriologists on characterization and classification of bacterial types. J Bacteriol. 1917;2:505-66

36. Migula W. Über ein neues system der bakterien. Arb Bakteriol Inst Karlsruhe. 1894;1:235-8.

37. Doudoroff M, Palleroni NJ. Genus Migula 1894, 237; Nom. cons. Opin. 5, Jud. Comm. 1952, 121. In: Buchanan RE, Gibbons NE, editors. Bergey's manual of determinative bacteriology. 8th ed. Baltimore: The Williams and Wilkins Co.; 1974. p. 217-43.

38. Commission J. Opinion 5: conservation of the generic name Pseudomonas Migula 1894 and designation of Pseudomonas aeruginosa (Schroeter) Migula 1900 as type species. Int Bull Bacteriol Nomencl Taxon. 1952;2:121-2.

39. Palleroni NJ. Pseudomonadaceae. Bergey's Manual of Systematic Bacteriology. In: Krieg NR, Holt JG, editors. Baltimore: The Williams and Wilkins Co; 1984: p. 141-99.

40. Ashburner M, Ball CA, Blake JA, Botstein D, Butler H, Cherry JM, et al. Gene ontology: tool for the unification of biology. Nat Genet. 2000;25:25-9.

41. Tamura K, Stecher G, Peterson D, Filipski A, Kumar S. MEGA6: molecular evolutionary genetics analysis version 6.0. Mol Biol Evol. 2013;30:2725-9. 